\title{
WOOD FLY ASH STABILIZED ROAD BASE LAYERS WITH HIGH RECYCLED ASPHALT PAVEMENT CONTENT
}

\section{PETERIS SKELS ${ }^{1 *}$, VIKTORS HARITONOVS ${ }^{2}$, EDVARDS PAVLOVSKIS ${ }^{3}$ \\ ${ }^{1-2}$ Dept of Roads and Bridges, Faculty of Civil Engineering, Riga Technical University, Riga, Latvia \\ ${ }^{3}$ Road building materials laboratory, Ltd. "Binders", Riga, Latvia}

Received 14 January 2020; accepted 28 February 2020

\begin{abstract}
Wood fly ash stabilised road base layers with high recycled asphalt pavements content was studied both at the laboratory and in-situ. The original recipe was chosen based on an actual stabilised pavement base layer design with cement CEM II/B-T 42.5R but optimised using wood fly ash. The existing road base layer from gravel was mixed with dolomite aggregate and recycled asphalt pavement, adding cement and wood fly ash at different proportions. The mixture was compacted at optimal water content according to the Standard Proctor test and further conditioned. Resistance to freezing and thawing of hydraulically bound mixtures was checked after 28 days of conditioning. Even 50 cycles of freezing and thawing were used. Test results indicated wood fly ash as an effective alternative to the typically used cement for road base stabilisation, including recycled asphalt pavement material. Three hydraulically bound mixtures were chosen for test sections in the pilot project. The project includes five different sections with three different hydraulic binder recipes. The performance of each section was evaluated.
\end{abstract}

Keywords: fly ash, hydraulically bound mixtures, stabilisation, recycled asphalt.

\footnotetext{
* Corresponding author. E-mail: peteris.skels_1@rtu.lv

Peteris SKELS (ORCID ID 0000-0002-1337-5114)

Viktors HARITONOVS (ORCID ID 0000-0003-3119-2677) 


\section{Introduction}

Climatic constraints, material properties of bound and unbound road pavement structural layers, and subgrade are well-known phenomena. The magnitude of this road construction operational problem in Latvia has been illustrated by the fact that with traditional methods (materials and technologies), the deficit of road reconstruction works of asphalt roads has reached 4068 million euro (Bērzinšs, 2016). In comparison, the annual road construction budget in Latvia is approximately 350 million euro. Due to increased costs of materials and risen environmental awareness, there is a definite need for structured research on possibilities, properties, and technologies to use reclaimed asphalt pavement (RAP). Reclaimed asphalt pavement is considered a good alternative to non-renewable natural resources for road foundation from technical, economic, and environmental perspectives. Before using RAP in road foundation, it usually needs to be stabilised with a binder - either bitumen, cement, or lime.

Furthermore, proper design procedures and calculations shall be provided using stabilised RAP. It is challenging due to high material anisotropy and lack of data sources about the quality and parameters of the existing pavement. However, insufficient information available about the design parameters of the RAP materials. There are already few projects finished in Latvia, where cement stabilised RAP was used as a road base layer above the existing old road structure.

On the other hand, also bio-fuel fly ashes have been successfully used in road construction in many pilot-projects in Europe (Bohrn \& Stampfer, 2014; Bjurström \& Herbert, 2009; Mácsik et al., 2004, 2009; Mácsik \& Svedberg, 2006; Supancic \& Odernberger 2012; Svedberg et al., 2008; Vanhanen et al., 2014; Vestin et al., 2012). Stabilised roads show enhanced durability and bearing capacity relative to the conventionally designed road sections in the same circumstances. Frost susceptibility, heave, deformation, and cracking problems are reduced. Findings in previous studies indicate that biofuel fly ashes are an effective alternative to cement, partly substituting it, leading to environmentally and economically more feasible solutions (Skels et al., 2017).

This research accumulates information about the testing procedures and design approaches for either a new or rehabilitated pavement structure. Stabilised RAP road base layers are used both with cement and fly ash both at laboratory and in-situ. 


\subsection{Methods}

\subsection{Laboratory testing}

Natural unbound material consisting from $21 \%$ of recycled asphalt pavement (RAP), $50 \%$ of gravel (existing material from pavement base), and $29 \%$ of $0 / 45$ fractioned dolomite, was mixed with eleven different admixtures (cement (CEM) and fly ash (FA)):

- $1.5 \%$ CEM II/ B-T 42.5R;

- 2.5\% CEM II/ B-T 42.5R;

- 3.5\% CEM II/ B-T 42.5R;

- $1.5 \%$ CEM II/ B-T 42.5R + 6\% Fly ash;

- $1.5 \%$ CEM II/ B-T 42.5R + 20\% Fly ash;

- $1.5 \%$ CEM II/ B-T $42.5 \mathrm{R}+30 \%$ Fly ash;

- $2.5 \%$ CEM II/ B-T $42.5 \mathrm{R}+10 \%$ Fly ash;

- $2.5 \%$ CEM II/ B-T 42.5R + 20\% Fly ash;

- $2.5 \%$ CEM II/ B-T $42.5 \mathrm{R}+30 \%$ Fly ash;

- $20 \%$ Fly ash;

- $30 \%$ Fly ash.

These eleven different compositions were chosen based on local experience in road layer stabilisation (recycling) and previous studies on this particular fly ash as an admixture (Skels et al., 2017). Figure 1 shows particle distribution, and Table 1 presents the chemical composition of used fly ash.

Optimal moisture content for all those mixtures was determined by standard Proctor compaction test by LVS EN 13286-2:2012L Unbound

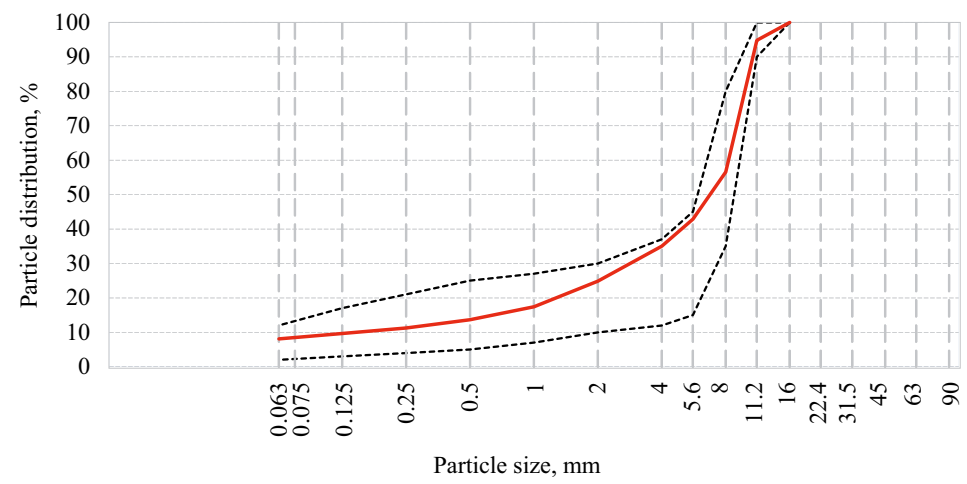

Figure 1. Particle distribution of the unbound material mixture
Wood Fly Ash

Stabilized Road Base

Layers With High

Recycled Asphalt

Pavement Content 
Table 1. Chemical composition of biofuel fly ash

\begin{tabular}{lcc}
\hline \multicolumn{1}{c}{ Chemical compound } & Composition, \% & Precision, \% \\
\hline $\mathrm{SiO}_{2}$ & 55.60 & 0.7 \\
$\mathrm{R}_{2} \mathrm{O}_{3}\left(\mathrm{Al}_{2} \mathrm{O}_{3}+\mathrm{Fe}_{2} \mathrm{O}_{3}\right)$ & 10.48 & 0.7 \\
$\mathrm{CaO}$ & 22.40 & 0.5 \\
$\mathrm{MgO}$ & 2.63 & 0.3 \\
$\mathrm{Fe}_{2} \mathrm{O}_{3}$ & 1.41 & 0.1 \\
$\mathrm{~K}_{2} \mathrm{O}$ & 1.77 & 0.3 \\
$\mathrm{Na}_{2} \mathrm{O}$ & 1.39 & 0.1 \\
$\mathrm{Al}_{2} \mathrm{O}_{3}=\mathrm{R}_{2} \mathrm{O}_{3}-\mathrm{Fe}_{2} \mathrm{O}_{3}$ & 9.07 & 0.5 \\
$\mathrm{SO}_{3}$ & 4.60 & 0.5 \\
$\mathrm{Hydraulic} \mathrm{modulus}$ & 1.74 & - \\
\hline
\end{tabular}

and hydraulically bound mixtures - Part 2: Test methods for laboratory reference density and water content - Proctor compaction. Stabilized unbound material samples were tested in unconfined compression test (UCS) by LVS EN 13286-41:2013L Unbound and hydraulically bound mixtures - Part 41: Test method for the determination of the compressive strength of hydraulically bound mixtures and LVS EN 13286-43:2003 Unbound and hydraulically bound mixtures - Part 43: Test method for the determination of the modulus of elasticity of hydraulically bound mixtures. Furthermore, the resistance to freezing and thawing was also tested for all the recipes by LVS CEN/TS 13286-54:2015 Unbound and hydraulically bound mixtures - Part 54: Test method for the determination of frost

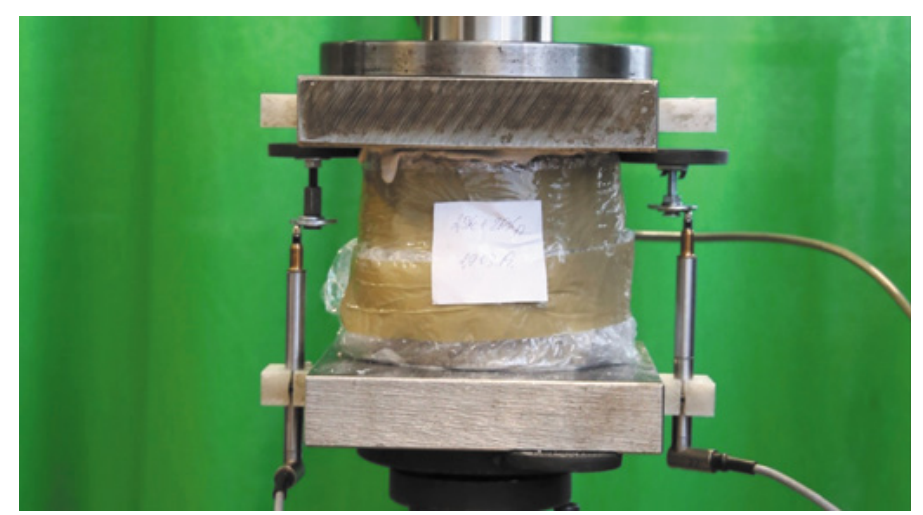

Figure 2. UCS testing of sample (2.5\% CEM II/ B-T $42.5 \mathrm{R}+20 \%$ Fly ash) 
susceptibility - resistance to freezing and thawing of hydraulically bound mixtures.

Universal testing apparatus Instron 8202 (250 kN load frame) was used (Figure 2) after conditioning by LVS EN 13286-50:2013L Unbound and hydraulically bound mixtures - Part 50: Method for the manufacture of test specimens of hydraulically bound mixtures using Proctor equipment or vibrating table compaction.

Specifications, as reported in LVS EN 14227-15:2016 Hydraulically bound mixtures - Specifications - Part 15: Hydraulically stabilised soils used to classify reached compressive strength based on UCS values.

\subsection{In-situ test trials}

Three hydraulically bound mixtures were chosen for test sections in the pilot project. The project includes five different sections with three different hydraulic binder recipes (Table 2).

About $20 \mathrm{~cm}$ thickness of the stabilised road surface layer was constructed using the so-called cold recycling method at each section of $75 \mathrm{~m}$ ( $375 \mathrm{~m}$ in total). Works were performed in the following stages, and the following actions were performed:

1) preparation of the existing top layer before construction of the stabilised layer;

2) delivery of materials (RAP and dolomite aggregate);

3) distribution of materials just as layer composition in each fullscale test section;

4) distribution of cement and fly ash;

5) cold recycling;

6) surface profiling and roller compaction;

7) top coating with bitumen.
Wood Fly Ash

Stabilized Road Base

Layers With High

Recycled Asphalt

Pavement Content

Table 2. Composition in five different sections in the pilot project

\begin{tabular}{|c|c|c|c|c|c|}
\hline \multirow{2}{*}{$\begin{array}{l}\text { Construction } \\
\text { thickness }\end{array}$} & \multicolumn{5}{|c|}{ Section } \\
\hline & No. 1 & No. 2 & No. 3 & No. 4 & No. 5 \\
\hline $10 \mathrm{~cm}$ & $\begin{array}{c}\text { Dolomite } \\
\text { aggregate } \\
\text { mixture 0/45 }\end{array}$ & $\begin{array}{c}\text { Dolomite } \\
\text { aggregate } \\
\text { mixture } 0 / 45\end{array}$ & $\begin{array}{l}\text { Reclaimed } \\
\text { asphalt } \\
\text { pavement }\end{array}$ & $\begin{array}{l}\text { Reclaimed } \\
\text { asphalt } \\
\text { pavement }\end{array}$ & $\begin{array}{c}\text { Dolomite } \\
\text { aggregate } \\
\text { mixture } 0 / 45\end{array}$ \\
\hline $10 \mathrm{~cm}$ & \multicolumn{5}{|c|}{ Existing gravel } \\
\hline $\begin{array}{l}\text { Hydraulic } \\
\text { binder }\end{array}$ & Fly ash $20 \%$ & $\begin{array}{c}\text { Fly ash } 20 \% \text {, } \\
\text { Portland } \\
\text { cement } 1.5 \%\end{array}$ & $\begin{array}{c}\text { Fly ash } 20 \% \text {, } \\
\text { Portland } \\
\text { cement } 1.5 \%\end{array}$ & $\begin{array}{c}\text { Portland } \\
\text { cement } 3.5 \%\end{array}$ & $\begin{array}{c}\text { Portland } \\
\text { cement } 3.5 \%\end{array}$ \\
\hline
\end{tabular}




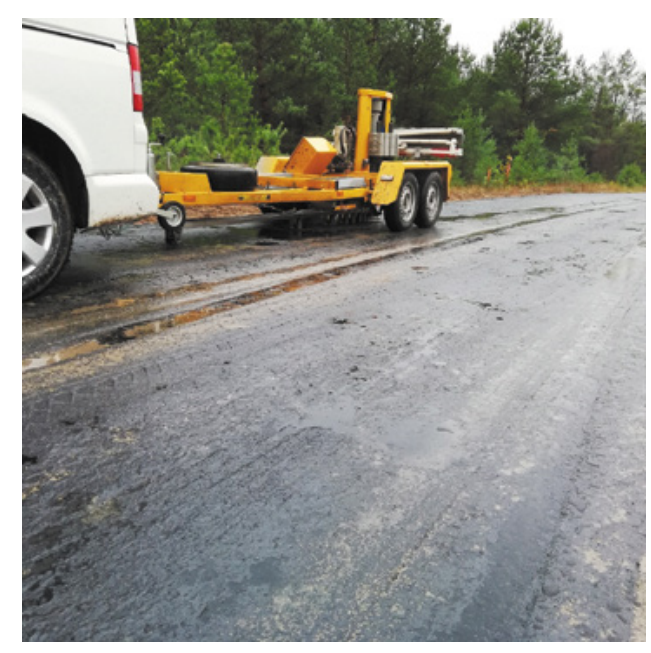

Figure 3. Falling weight deflectometer tests on site

As part of the quality control and assurance, the static Plate load test (PLT) in agreement to DIN 18134:2012-04 Soil - Testing procedures and testing equipment - Plate load test and falling-weight deflectometer (FWD) was used for assessing the strength and stiffness of road construction layers. The performance of the constructed road was determined seven days after construction using PLT and FWD. Dynatest 8000 FWD by Latvian State Roads was used for testing the pavement structure by $50 \mathrm{kN}$ load on a $30 \mathrm{~cm}$ plate (Figure 3).

Two weeks after the road surface construction and conditioning, the traffic was opened on the trial section. The heavy lorries were driving back and forth from the Sand quarry next to the pilot project. Road performance was further monitored and evaluated.

\section{Results and discussion}

Unconfined Compression strength (UCS) results for each specimen are shown in Table 3. In total, 72 tests were performed after 28 days of conditioning in accordance to LVS EN 13286-50:2013L and some samples after freezing and thawing recipes in accordance to LVS CEN/TS 1328654:2015 Unbound and hydraulically bound mixtures - Part 54: Test method for the determination of frost susceptibility - Resistance to freezing and thawing of hydraulically bound mixtures - all recipes with six samples, except 20FA and 1.5CEM mixtures, where nine samples were analysed for each. 
Table 3. Unconfined compression strength and modulus of elasticity results

\begin{tabular}{|c|c|c|c|c|c|c|c|c|c|}
\hline \multirow{2}{*}{ Binder } & \multicolumn{2}{|c|}{ Reference sample } & \multicolumn{2}{|c|}{10 freezing cycles } & \multicolumn{2}{|c|}{$\begin{array}{l}25 \text { freezing } \\
\text { cycles }\end{array}$} & \multicolumn{2}{|c|}{$\begin{array}{c}50 \text { freezing } \\
\text { cycles }\end{array}$} & \multirow{2}{*}{ 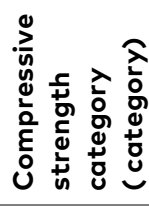 } \\
\hline & $\begin{array}{l}\text { UCS, } \\
\text { MPa }\end{array}$ & $E, M P a$ & $\begin{array}{l}\text { UCS, } \\
\text { MPa }\end{array}$ & $E, M P a$ & $\begin{array}{l}\text { UCS, } \\
\text { MPa }\end{array}$ & $E, M P a$ & $\begin{array}{l}\text { UCS, } \\
\text { MPa }\end{array}$ & $E, M P a$ & \\
\hline 2OFA & $\begin{array}{r}1.15 \\
\pm 0.28\end{array}$ & - & $\begin{array}{r}1.04 \\
\pm 0.24\end{array}$ & - & $\begin{array}{r}1.01 \\
\pm 0.31\end{array}$ & & $\begin{array}{r}0.73 \\
\pm 0.004\end{array}$ & - & $C_{0.8 / 1.0}$ \\
\hline 30FA & $\begin{array}{r}2.82 \\
\pm 0.63 \\
\end{array}$ & $\begin{array}{r}334.00 \\
\pm 33.00 \\
\end{array}$ & $\begin{array}{r}2.10 \\
\pm 0.45 \\
\end{array}$ & $\begin{array}{r}110.67 \\
\pm 25.49 \\
\end{array}$ & - & - & - & - & $\mathrm{C}_{2.0 / 2.5}$ \\
\hline 1.5CEM & $\begin{array}{r}2.45 \\
\pm 0.48\end{array}$ & $\begin{array}{r}333.67 \\
\pm 115.38\end{array}$ & $\begin{array}{r}2.06 \\
\pm 0.04\end{array}$ & $\begin{array}{r}157.50 \\
\pm 13.50\end{array}$ & $\begin{array}{r}2.17 \\
\pm 0.25\end{array}$ & $\begin{array}{r}146.50 \\
\pm 13.50\end{array}$ & $\begin{array}{r}3.03 \\
\pm 0.05 \\
\end{array}$ & $\begin{array}{r}327.00 \\
\pm 37.00\end{array}$ & $\mathrm{C}_{2.0 / 2.5}$ \\
\hline $\begin{array}{c}\text { 1.5CEM + } \\
\text { 6FA }\end{array}$ & $\begin{array}{r}2.16 \\
\pm 0.23 \\
\end{array}$ & $\begin{array}{r}371.00 \\
\pm 45.72 \\
\end{array}$ & $\begin{array}{r}1.82 \\
\pm 0.31 \\
\end{array}$ & $\begin{array}{r}176.67 \\
\pm 56.35 \\
\end{array}$ & - & - & - & - & $\mathrm{C}_{2.0 / 2.5}$ \\
\hline $\begin{array}{c}1.5 \mathrm{CEM}+ \\
\text { 2OFA }\end{array}$ & $\begin{array}{r}2.25 \\
\pm 0.18\end{array}$ & $\begin{array}{r}234.67 \\
\pm 41.06\end{array}$ & $\begin{array}{r}1.65 \\
\pm 0.18\end{array}$ & $\begin{array}{r}119.50 \\
\pm 29.50\end{array}$ & - & - & - & - & $\mathrm{C}_{2.0 / 2.5}$ \\
\hline $\begin{array}{c}\text { 1.5CEM + } \\
\text { 3OFA }\end{array}$ & $\begin{array}{r}2.95 \\
\pm 0.16\end{array}$ & $\begin{array}{r}346.00 \\
\pm 48.00\end{array}$ & $\begin{array}{r}1.93 \\
\pm 0.49\end{array}$ & $\begin{array}{r}231.00 \\
\pm 23.00\end{array}$ & - & - & - & - & $\mathrm{C}_{2.0 / 2.5}$ \\
\hline 2.5CEM & $\begin{array}{r}3.37 \\
\pm 0.19\end{array}$ & $\begin{array}{r}493.00 \\
\pm 0.00\end{array}$ & $\begin{array}{r}3.51 \\
\pm 0.15\end{array}$ & $\begin{array}{l}425.00 \\
\pm 18.24\end{array}$ & - & - & - & - & $\mathrm{C}_{3.0 / 4.0}$ \\
\hline $\begin{array}{c}2.5 \mathrm{CEM}+ \\
\text { 10FA }\end{array}$ & $\begin{array}{r}3.92 \\
\pm 0.26 \\
\end{array}$ & $\begin{array}{r}501.50 \\
\pm 107.50 \\
\end{array}$ & $\begin{array}{r}3.78 \\
\pm 0.08 \\
\end{array}$ & $\begin{array}{r}252.33 \\
\pm 23.57 \\
\end{array}$ & - & - & - & - & $\mathrm{C}_{3.0 / 4.0}$ \\
\hline $\begin{array}{c}2.5 \mathrm{CEM}+ \\
20 F A\end{array}$ & $\begin{array}{r}4.77 \\
\pm 0.69 \\
\end{array}$ & $\begin{array}{r}697.33 \\
\pm 313.37 \\
\end{array}$ & $\begin{array}{r}3.92 \\
\pm 0.57 \\
\end{array}$ & $\begin{array}{r}315.67 \\
\pm 90.34 \\
\end{array}$ & - & - & - & - & $\mathrm{C}_{3.0 / 4.0}$ \\
\hline $\begin{array}{c}2.5 \mathrm{CEM}+ \\
\text { 3OFA }\end{array}$ & $\begin{array}{r}4.29 \\
\pm 0.51\end{array}$ & $\begin{array}{r}443.50 \\
\pm 168.50 \\
\end{array}$ & $\begin{array}{r}3.80 \\
\pm 0.11\end{array}$ & $\begin{array}{l}288.33 \\
\pm 81.13\end{array}$ & - & - & - & - & $C_{3.0 / 4.0}$ \\
\hline 3.5CEM & $\begin{array}{r}5.37 \\
\pm 0.19\end{array}$ & $\begin{array}{r}2217.67 \\
\pm 479.95\end{array}$ & $\begin{array}{r}5.37 \\
\pm 0.14\end{array}$ & $\begin{array}{r}1771.68 \\
\pm 412.93\end{array}$ & - & - & - & - & $\mathrm{C}_{4.0 / 5.0}$ \\
\hline
\end{tabular}

Note: UCS - unconfined compression strength; $E$ - modulus of elasticity.

Reference laboratory samples indicate that by adding more cement, both UCS and stiffness ( $E$ modulus) increase for the same conditioning (Figures 4-6). Even if UCS and $E$ modulus values increase by adding $10 \%$ to $30 \%$ of fly ash, the maximum values (at $3.5 \%$ cement) never reached with substituting cement with fly ash, especially the stiffness significantly reduced, reducing the cement in the composition. Results 

ENGINEERING

2021/16(2)

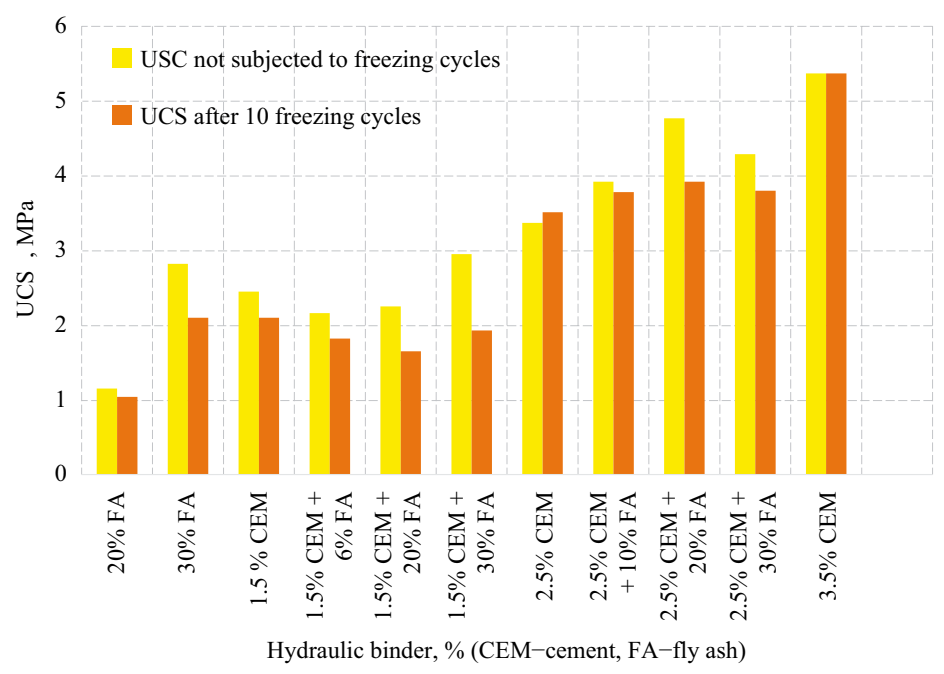

Figure 4. Unconfined compression strength for reference samples and after ten freezing cycles

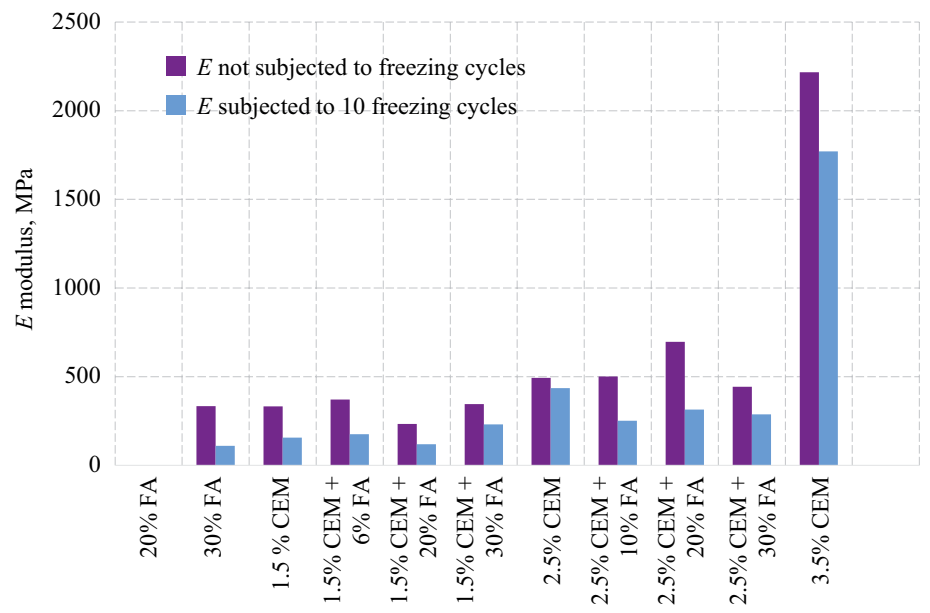

Hydraulic binder, \% (CEM-cement, FA-fly ash)

Figure 5. E modulus values for reference samples and after ten freezing cycles

indicate that freezing and thawing resistance is reduced by adding more fly ash (Figure 6).

Nevertheless, each testing result is classified based on UCS values in agreement to LVS EN 14227-15:2016 specifications - category (Table 3). 


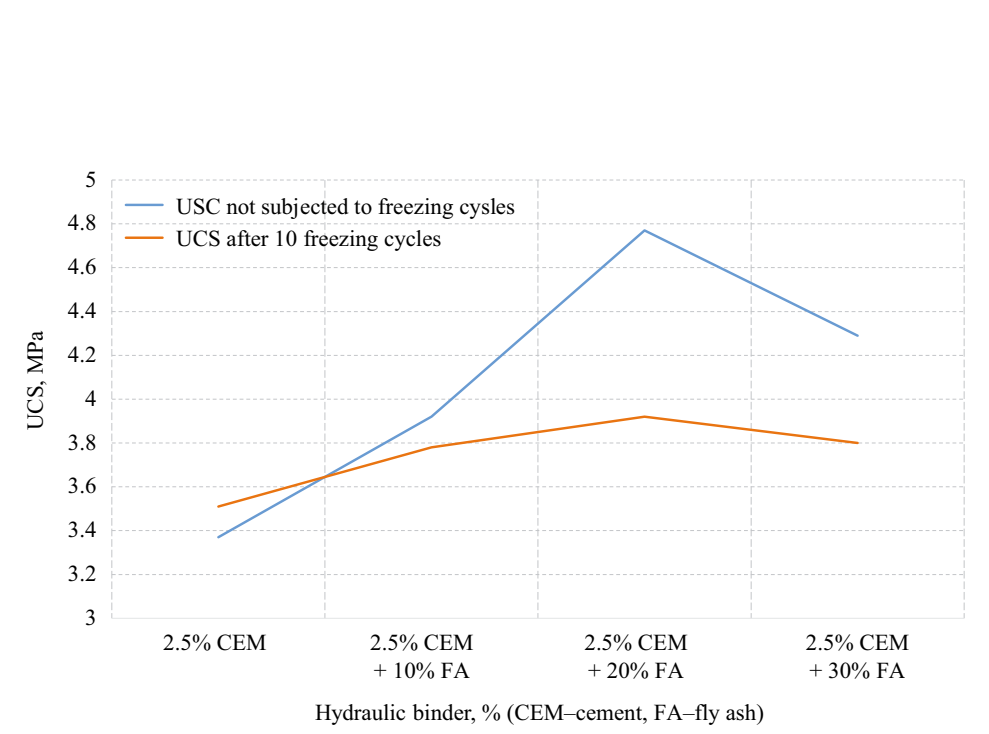

Peteris Skels, Viktors Haritonovs, Edvards Pavlovskis Wood Fly Ash Stabilized Road Base Layers With High Recycled Asphalt Pavement Content

Note: samples with $2.5 \%$ cement in the composition.

Figure 6. Unconfined compression strength for reference samples and after ten freezing cycles

UCS based on categories are consistent for 1.5\% CEM and 2.5\% CEM samples with and without fly ash with up to $30 \%$ fly ash content.

The full-scale test site results confirmed results obtained in the laboratory - by applying more cement, both PLT and FWD test results indicated that stiffness and strength are increased (Table 4).

Table 4. Plate loading test and falling weight deflectometer results

\begin{tabular}{|c|c|c|c|c|c|c|}
\hline \multirow{4}{*}{ 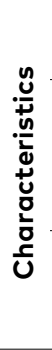 } & \multirow{2}{*}{ Materials } & \multicolumn{5}{|c|}{ Full-scale test sections with a thickness of $20 \mathrm{~cm}$} \\
\hline & & No. 1 & No. 2 & No. 3 & No. 4 & No. 5 \\
\hline & \multirow{2}{*}{$\begin{array}{c}\text { Aggregates } \\
\text { Binder }\end{array}$} & \multicolumn{2}{|c|}{$\begin{array}{c}\text { Dolomite aggregate mixture } \\
0 / 45 \\
+ \text { existing gravel material }\end{array}$} & \multicolumn{2}{|c|}{$\begin{array}{c}\text { RAP } \\
+ \text { existing gravel } \\
\text { material }\end{array}$} & $\begin{array}{c}\text { Dolomite aggregate } \\
\text { mixture } 0 / 45 \\
+ \text { existing gravel } \\
\text { material } \\
\end{array}$ \\
\hline & & Fly ash $20 \%$ & $\begin{array}{c}\text { Fly ash } 20 \% \\
\text { + Cement } \\
1.5 \%\end{array}$ & $\begin{array}{c}\text { Fly ash } 20 \% \\
+ \text { Cement } \\
1.5 \%\end{array}$ & $\begin{array}{c}\text { Cement } \\
3.5 \%\end{array}$ & Cement $3.5 \%$ \\
\hline & $\begin{array}{l}\text { Compaction } \\
E_{V_{2}} / E_{V_{1}}\end{array}$ & 1.85 & 1.73 & 2.21 & 2.25 & 2.13 \\
\hline & $E_{V_{2}}, \mathrm{MPa}$ & 177.50 & 205.90 & 187.20 & 212.30 & 220.20 \\
\hline & $\begin{array}{l}\text { Deflection } \\
\text { at central } \\
\text { ensor D1, } \mu \mathrm{m}\end{array}$ & $1774 \pm 392$ & $1660 \pm 684$ & $1280 \pm 302$ & $545 \pm 92$ & $462 \pm 245$ \\
\hline
\end{tabular}

Note: deflection at central FWD sensor - D1. $E_{V_{1}}$ - the strain modulus of the first loading curve (referred to as the primary strain modulus) in PLT. $E_{V_{2}}$ - the strain modulus of the second loading curve (referred to as the secondary strain modulus) in PLT. 
When the traffic was opened, the performance of each section was evaluated. After the first two weeks of operation, it was clear that only the first two sections with $3.5 \%$ cement sustain the load. In contrast, other sections with reduced cement content and fly ash encountered rutting and layer settling problems - summarised in Table 5.

Table 5. Summary of detected defects during the monitoring period after construction

\begin{tabular}{|c|c|c|c|c|}
\hline No. & $\begin{array}{c}\text { Type } \\
\text { of damage }\end{array}$ & Description of the defect & $\begin{array}{l}\text { Full-scale } \\
\text { test section }\end{array}$ & $\begin{array}{l}\text { Section } \\
\text { length }\end{array}$ \\
\hline 1. & $\begin{array}{l}\text { Surface erosion } \\
\text { (separation } \\
\text { of aggregates, } \\
\text { debris) }\end{array}$ & $\begin{array}{l}\text { Slight displacement of the material laterally } \\
\text { to form a } 1-2 \mathrm{~cm} \text { layer of mud has been } \\
\text { observed. Ruts up to } 10 \mathrm{~mm} \text { were detected. } \\
\text { The bearing capacity and service life of the } \\
\text { pavement are satisfactory. }\end{array}$ & $\begin{array}{l}\text { Full- scale test } \\
\text { section No. } 5 \\
\text { and No. } 4 \\
\text { (only cement } \\
\text { used for } \\
\text { stabilisation) }\end{array}$ & $150 \mathrm{~m}$ \\
\hline 2. & Rutting & $\begin{array}{l}\text { High lateral displacement of materials on the } \\
\text { surface of the construction was founded-an } \\
\text { erosion layer (mud) of 30-50 mm thickness } \\
\text { is formed. Ruts up to } 100 \mathrm{~mm} \text { were detected. } \\
\text { The load-bearing capacity of the layer and } \\
\text { its service life has been significantly reduced, } \\
\text { and because of precipitation, the constructed } \\
\text { layer is decomposed. The constructed } \\
\text { section is difficult to pass, and the stabilised } \\
\text { pavement material must be removed. }\end{array}$ & $\begin{array}{l}\text { Full-scale test } \\
\text { section No. } 3 \\
\text { and No. } 2 \\
\text { (fly ash with } \\
\text { cement } \\
\text { used for } \\
\text { stabilisation) }\end{array}$ & $150 \mathrm{~m}$ \\
\hline 3. & Layer settling & $\begin{array}{l}\text { Ruts up to } 130 \mathrm{~mm} \text { were detected. High } \\
\text { lateral displacement of materials on the } \\
\text { surface of the construction was founded. } \\
\text { An erosion layer (mud) of } 100 \mathrm{~mm} \text { thickness } \\
\text { is formed. The load-bearing capacity of the } \\
\text { section and its service life has been lost } \\
\text { due to the decomposition of the associated } \\
\text { boundary layer, transport loads and } \\
\text { environmental conditions. The constructed } \\
\text { section is not passable, and the stabilised } \\
\text { pavement material must be removed. }\end{array}$ & $\begin{array}{l}\text { Full-scale } \\
\text { test section } \\
\text { No. } 1 \text { (only fly } \\
\text { ash used for } \\
\text { stabilisation) }\end{array}$ & $75 \mathrm{~m}$ \\
\hline 4. & $\begin{array}{l}\text { Network } \\
\text { of cracks }\end{array}$ & - & - & - \\
\hline
\end{tabular}




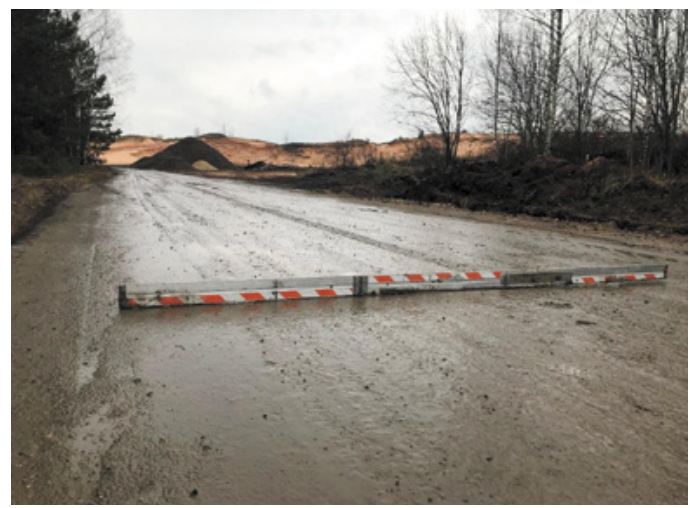

Figure 7. Full-scale test section No. 1

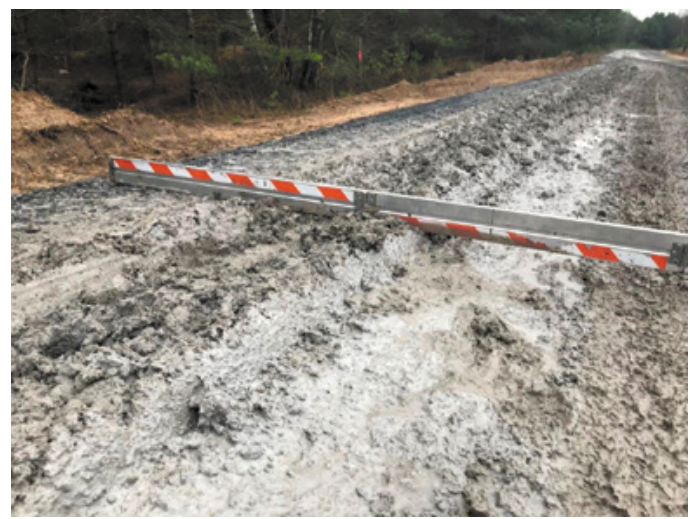

Figure 8. Full-scale test section No. 2

High humidity throughout the curing time was one of the main reasons stabilisation using fly ash alone failed during the full-scale test site construction (Figure 7). The experimental section was loaded with heavy traffic from sand query soon after the construction (14 days considered to short conditioning time - 28 days curing was applied at the laboratory). The addition of $1.5 \%$ Portland cement to fly ash resulted in significant improvement in performance. However, still, the rutting problem was identified (Figure 8). More extensive studies are essential for evaluating the impact of the construction period - low air temperature and rain (water content). On the other hand, the pavement 


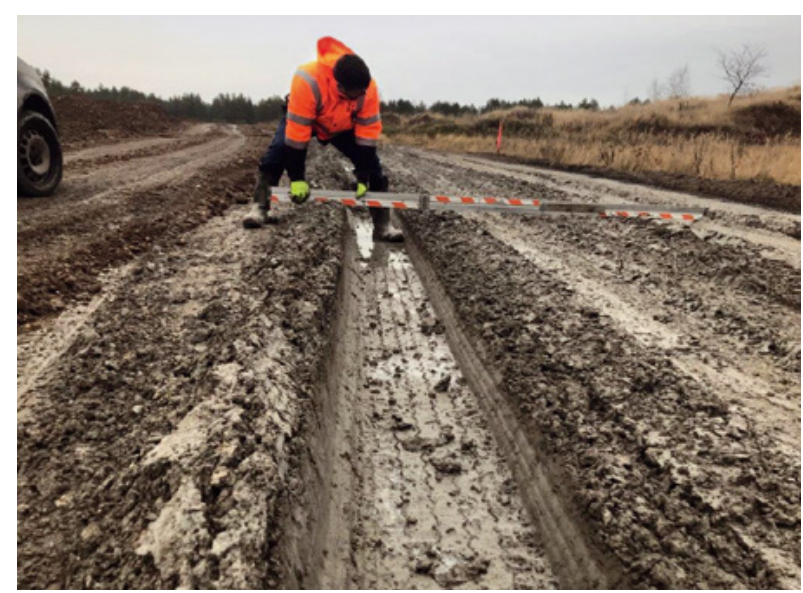

Figure 9. Full-scale test section No. 5

surface layer stabilised with 3.5\% cement showed relatively good performance and sustained the load even at the existing conditioning and loading conditions (Figure 9). However, it is recommended to build the test-trial in the spring-summer season and conditioning the pavement structure for at least four weeks before opening heavy traffic to evaluate the fly ash stabilisation effect properly.

The laboratory and in-situ test trial results lead to the concluding remarks that fly ash is a practical subsidiser of cement only if proper curing is ensured. It supposed to be protected from direct water infiltration with a surface coating to use fly ash stabilised pavement structural layers.

\section{Conclusions}

1. Cement CEM II/B-T 42.5R and fly ash used are suitable for this type of unbound material stabilisation.

2. Test results show very consistent road surface layer strength and stiffness increase by adding more cement.

3. Test results showing very consistent road surface layer strength and stiffness increase by adding more fly ash. However, above $30 \%$ of fly ash cause mixing the material and compacting it properly. 
Some of the results indicate that $20 \%$ of fly ash is a more optimal option than $30 \%$.

4. Test results showing that fly ash mixtures without cement are susceptible to freezing and thawing cycles, and both strength and stiffness significantly reduced after 10 to 50 cycles.

5. Test results also indicate that test samples are gaining strength and stiffness after 28 days of curing.

6. Even the laboratory test results showed promising results for the fly ash stabilised unbound material, the test trial in-situ indicated several challenges: rutting and layer were settling with reduced cement and increased fly ash content in mixtures.

7. Laboratory and in-situ test results indicate that particular fly ash from a specific combustion plant is a good stabiliser in pavement structural layers protected from direct water infiltration and ensuring proper conditioning before the exploitation under traffic load. However, laboratory test results indicating that strength and stiffness is reduced by freezing and thawing for mixtures with fly ash. Simultaneously, only cement stabilised samples show an even increase due to longer conditioning time usually - these findings contrast to the reported results in the literature.

8. This study indicated the limits of particular fly ash usage for pavement structural layers. However, unconfined compression strength, based on compressive strength category $\left(R_{c}\right)$, is reduced by adding fly ash to the hydraulically bound material mixture.

\section{Funding}

This study was co-financed by the European Regional Development Fund (ERDF). Measure 1.1.1.1 "Industry-Driven Research" of specific objective 1.1.1 "To increase the research and innovation capacity of scientific institutions of Latvia and their ability to attract external funding by investing in human resources and infrastructure" within the project: No. 1.1.1.1/16/A/148 "Innovative use of reclaimed asphalt pavement for sustainable road construction layers".
Wood Fly Ash

Stabilized Road Base

Layers With High

Recycled Asphalt

Pavement Content 


\section{REFERENCES}

Bērzin̄š, A. (2016, February). Latvijas Ceḷu būvētājs: „Projektēšanai nedrīkst taupit". Autocel̦u Avīze, p. 5. (in Latvian)

Bohrn, G., \& Stampfer, K. (2014). Untreated wood ash as a structural stabilising material in forest roads. Croatian Journal of Forest Engineering: Journal for Theory and Application of Forestry Engineering, 35(1), 81-89.

Bjurström, H., \& Herbert, R. (2009). The Swedish Ash Programme 2002-2008. Biomass, wastes, peat-any solid fuel but coal. Project number Q6-670. A synthesis of the ash programme in English. VÄRMEFORSK Service AB.

DIN 18134:2012-04 Soil - Testing procedures and testing equipment - Plate load test

LVS CEN/TS 13286-54:2015 Unbound and hydraulically bound mixtures - Part 54: Test method for the determination of frost susceptibility - Resistance to freezing and thawing of hydraulically bound mixtures

LVS EN 13286-2:2012L Unbound and hydraulically bound mixtures - Part 2: Test methods for laboratory reference density and water content - Proctor compaction

LVS EN 13286-41:2013L Unbound and hydraulically bound mixtures - Part 41: Test method for the determination of the compressive strength of hydraulically bound mixtures

LVS EN 13286-43:2003 Unbound and hydraulically bound mixtures - Part 43: Test method for the determination of the modulus of elasticity of hydraulically bound mixtures

LVS EN 13286-50:2013L Unbound and hydraulically bound mixtures - Part 50: Method for the manufacture of test specimens of hydraulically bound mixtures using Proctor equipment or Vibrating table compaction

LVS EN 14227-15:2016 Hydraulically bound mixtures - Specifications - Part 15: Hydraulically stabilised soils

Mácsik, J., Svedberg, B., Lenströmer, S., \& Nilsson, T. (2004). FACE Flygaska i geotekniska anläggningar, Etapp 1: Inventering/Tillämplighet. Värmeforsks rapportserie Q4-107, Miljöriktiganvändning av askor, (870). (in Swedish)

Mácsik, J., \& Svedberg, B. (2006). Skogsbilvägsrenovering av Ehnsjövägen, Hallstavik. Miljöriktig användning av askor, 968. (in Swedish)

Máscsik, J., Erlandsson, Å., \& Wexell, B. A. (2009). Flygaskagrönlutslamstabiliserad skogsbilväg-Fallstudie Iggesund [Fly ash and green liquor as binder in gravel road stabilization-Pilot study at Iggesund]. Värmeforsk Report, 1101. (in Swedish)

Skels, P., Bondars, K., \& Haritonovs, V. (2017). Wood fly ash stabilisation of unbound pavement layers. Proc. of the 19th ICSMGE.

Supancic, K. L. A. U. S., \& Obernberger, I. (2012). Wood ash utilisation as a binder in soil stabilisation for road construction \& first results of large-scale tests. 
Svedberg, B., Ekdahl, P., Mácsik, J., Maijala, A., Lahtinen, P., Hermansson, Å., ... \& Wood Fly Ash Stabilized Road Base Layers With High Edeskär, T. (2008). FUD-SALA: provsträcka med stabilisering av obundna lager Värmeforsk. (in Swedish)

Recycled Asphalt

Vanhanen, H., Dahl, O., \& Joensuu, S. (2014). Utilisation of wood ash as a Pavement Content road construction material-Sustainable use of wood ashes. Sustainable Environment Research, 24(6).

Vestin, J., Arm, M., Nordmark, D., Lagerkvist, A., Hallgren, P., \& Lind, B. (2012, May). Fly ash as a road construction material. In Conference on WASCON (pp. 1-8). 